by Jin-Yong Lee and Heejung Kim*

\title{
Special thanks to our peer reviewers for 2021
}

Department of Geology, Kangwon National University, Chuncheon 24341, Republic of Korea; *E-mail: episodes.j.me@gmail.com

(Received: November 20, 2021; Revised accepted: November 30, 2021)

https://doi.org/10.18814/epiiugs/2021/021030

Members of the editorial board and Publications Committee of Episodes express their appreciation to those who served as peer reviewers for Episodes in 2021.

\section{Editor-in-Chief: Jin-Yong Lee}

\section{Managing Editor: Heejung Kim}

Associated Editors: Hema Achyuthan, Laia Alegret, Kristine Asch, Margaret Brocx, Elizabeth Catlos, Chee-Ming Chan, Giuseppe Di Capua, Carlos Cónsole-Gonella, Sabina Dolenec, Andrea Festa, Stanley Finney, Gurmeet Kaur, Osamu Kazaoka, Heejung Kim, Jin-Yong Lee, Brian Marker, Jesús Martínez-Frías, Victor Mocanu, Nellia Mutemeri, Maria Dolores Pereira, Mihail Popescu, Brian Pratt, Elizabeth Rovere, Reimar Seltmann, Afroz Ahmad Shahd, Clara Vasconcelos, Wenjiao Xaio

Publications Committee: Maria Dolores Pereira, Stanley Finney, Giuseppe Di Capua, Gurmeet Kaur, Jin-Yong Lee

Episodes, established in 1961 as the flagship journal for the International Union of Geological Sciences (IUGS), has been contributing to the development of the Earth Sciences by, among the services that it can offer, providing support to the academic endeavors by its members in this field. As is well known, for a research paper to be published, it must undergo evaluation as a part of the editing process. In particular, our journal is known to have rigorous evaluation standards. In addition, the committee members conducting the evaluation dedicate much effort and commitment to guarantee the fairness of the evaluation and excellence of our published papers, which is why the evaluation takes time. Nonetheless, we have managed to reduce the required amount of time for evaluation through the efforts of the evaluation and editing committee over the last few years. The majority of the evaluation period is devoted to the time required by the committee to conduct its evaluation and the time used by the author for modifications. The editorial team and publication committee at Episode is putting all of its efforts toward minimizing this timeline, and these efforts require the commitment and sacrifice of the people tasked with editing as well as the evaluation committee. The editorial board members are composed of some of the most highly regarded subject matter experts in the field of Earth Sciences worldwide. Many of the editorial board members are also busy with other commitments, which is why we hesitate to place additional burdens on them when we request their evaluation. However, the great dedication to service and sacrifice displayed by the editorial members has allowed us to publish four improved editions of Episodes annually, acting as the driving force for development in Earth Sciences globally. Episodes, along with the Publication Committee, and on behalf of the authors and readers, would like to extend its most sincere gratitude for the swift and objective evaluation by the evaluation committee members. Moreover, Episodes is committed to continuing to raising the bar of its journal while providing quick services, and it would highly appreciate the support and interest of its members.

\author{
Aaron W. Johnson, Ph.D. \\ Aasif Lone, Ph.D. \\ Ashesh Siawal, Ph.D. \\ Bagci Utku, Ph.D. \\ Bo Wan, Ph.D. \\ Brian Pratt, Ph.D. \\ Brian Raymond Marker, Ph.D. \\ Charalambos Fassoulas, Ph.D. \\ D.M. Banerjee, Ph.D. \\ David Thiel, Ph.D. \\ Debo Ma, Ph.D. \\ Dongbok Shin, Ph.D.
}

\author{
Dongsheng Liu, Ph.D. \\ Eddy Poty, Ph.D. \\ Elena B. Naimark, Ph.D \\ Giuseppe Nirta, Ph.D. \\ Greg Street, Dic \\ Hendrik Falck, Ph.D. \\ Hugh Rollinson, Ph.D. \\ Ian Somerville, Dr. \\ Irfan Rashid, Ph.D. \\ Jacques Pironon, Ph.D. \\ Jinggui Sun, Ph.D. \\ Jin-Yong Lee, Ph.D.
}

\author{
Jochen Erbacher, Ph.D. \\ Jose Nespereira Jato, Ph.D. \\ Juan Carlos Gutierrez Marco, Ph.D. \\ Junfeng Zhang, Ph.D. \\ Jung Hun Seo, Ph.D. \\ Kiran Shanker Misra, Ph.D. \\ Landry Soh Tamehe, Ph.D. \\ Laura Gaggero, Ph.D. \\ Lucy E Edwards, Ph.D \\ Maria Henriques, Ph.D. \\ Michael James Cawthorne Walker, Ph.D. \\ Michiel van der Meulen, Ph.D.
}


Mirijam Vrabec, Ph.D.

Mostafa Redwan, Ph.D.

Paola Tartarotti, Ph.D.

Paolo Conti, Ph.D.

Pedro Huerta, Ph.D.

Pei Shang, Ph.D.

Per Ahlberg, Ph.D.

Phil Gibbard, Ph.D.Dos. Ph.D. Sc.D.
R.K. Bikramaditya Singh, Ph.D. Taher Shahin, Ph.D.

Takamoto Okudaira, Ph.D.

Tiago Alves, Ph.D.

Tolga Oyman, Ph.D.

V. Nandakumar, Ph.D.

Wenjiao Xiao, Ph.D.

Werner Piller, Ph.D.
Xi Chen, Ph.D.

Yu-Chul Park, Ph.D.

Zhen Qiu, Ph.D.

Zi-Fu Zhao, Ph.D.

(As of November 30, 2021) 